\title{
PENGARUH KIRIGAMI TERHADAP KEMAMPUAN MOTORIK HALUS ANAK KELOMPOK B1 DI TK IKAL WIDYA KUMARA SIDAKARYA
}

\author{
Maria Maha Dewi ${ }^{1}$ I.B Surya Manuaba ${ }^{2}$, G.N Sastra Agustika ${ }^{3}$ \\ 1,2,3 Jurusan Pendidikan Dasar \\ Universitas Pendidikan Ganesha \\ Singaraja, Indonesia \\ e-mail: mariadewi98@gmail.com¹, idabagussurya.manuaba@undiksha.ac.id², \\ gn.sastra.a@undiksha.ac.id ${ }^{3}$
}

\begin{abstract}
Abstrak
Penelitian ini bertujuan untuk mengetahui pengaruh kirigami terhadap kemampuan motorik halus anak kelompok B1 di TK Ikal Widya Kumara Sidakarya Tahun Ajaran 2018/2019. Jenis penelitian ini PreEksperimental Design dengan menggunakan desain penelitian One Group Pretest-Posttest Design. Populasi dari penelitian ini sama dengan jumlah sampel yaitu 27 anak. Hasil perhitungan data pretest dan posttest kemampuan motorik halus menunjukkan nilai rata-rata posttest lebih tinggi dari nilai rata-rata pretest (posttest $=64,22>$ pretest $=27,93$ ). Pengujian hipotesis yang digunakan adalah uji beda mean dengan menggunakan rumus uji varians. Kriteria pengujian pada taraf signifikansi $5 \%$ dengan $\mathrm{dk}=26$. Diperoleh harga $t_{\text {hitung }}=33,55>$ harga tabel $=2,056$. Sehingga dapat disimpulkan kirigami berpengaruh terhadap kemampuan motorik halus anak kelompok B1 di TK Ikal Widya Kumara Sidakarya Tahun Ajaran 2018/2019. Berdasarkan simpulan tersebut, maka disarankan kepada peneliti lain agar menggunakan kirigami untuk meningkatkan kemampuan motorik halus anak.
\end{abstract}

Kata-kata Kunci: kirigami, motorik halus, anak kelompok B1

\begin{abstract}
This study aimed to determine the effect of kirigami on the fine motor skills of children in the B1 group in Ikal Widya Kumara Sidakarya Kindergarten in Academic Year 2018/2019. This type of research is PreExperimental Design using research design One Group Pretest-Posttest Design. The population of this study is the same as the number of samples of 27 children. The results of the calculation of pretest and posttest data on fine motor skills showed that the average posttest score was higher than the average pretest (posttest $=64.22>$ pretest $=27.93$ ). Testing the hypothesis used is a different mean test using the variance test formula. Test criteria at a significance level of $5 \%$ with $\mathrm{dk}=26$. The price of $\mathrm{t}_{\text {count }}=33.55>$ the price of $t_{\text {table }}=2.056$. So that it can be concluded kirigami has an effect on the fine motor skills of children in group B1 in Kindergarten Ikal Widya Kumara Sidakarya Academic Year 2018/2019. Based on these conclusions, it was suggested to other researchers to use kirigami to improve children's fine motor skills.
\end{abstract}

Keywords: kirigami, fine motor, group children B1 


\section{PENDAHULUAN}

Pendidikan Anak Usia Dini (PAUD) adalah jenjang pendidikan sebelum jenjang pendidikan dasar yang merupakan suatu upaya pembinaan yang ditujukan bagi anak sejak lahir sampai dengan usia enam tahun. Pendidikan ini dilakukan melalui pemberian rangsangan untuk membantu pertumbuhan dan perkembangan jasmani dan rohani agar anak memiliki kesiapan dalam memasuki pendidikan lebih lanjut.

Anak usia dini adalah anak yang berada pada rentang usia 0-6 tahun. Pada masa ini juga disebut masa keemasan (golden age), dimana anak mengalami perkembangan yang dapat dengan mudah distimulasi, dan tidak lepas dari bantuan orang dewasa. Periode emas ini hanya berlangsung satu kali sepanjang rentang kehidupan manusia, oleh karena itu dibutuhkan sebuah pendidikan.

Menurut Triwiyanto (2014:66) mengatakan: "Pendidikan ialah sebuah upaya yang sengaja untuk membantu pertumbuhan dan perkembangan murid." Hal ini berarti pendidikan adalah sebuah pembelajaran yang diberikan secara sengaja untuk peserta didik guna tumbuh kembang anak berkembang dengan optimal. Untuk mengembangkan tumbuh kembang anak agar berkembang secara optimal dibutuhkan sebuah pendidikan yang sesuai dengan usianya.

Pendidikan sesuai usia telah dibuat untuk anak usia dini oleh Peraturan Menteri Pendidikan dan Kebudayaan Republik Indonesia Nomor 146 Tahun 2014 tentang Kurikulum Pendidikan Anak Usia Dini Pasal 2 ayat 1 yaitu PAUD diselenggarakan berdasarkan kelompok usia dan jenis layanannya yang meliputi.

a. Layanan PAUD untuk usia sejak lahir sampai dengan 6 (enam) tahun terdiri atas Taman Penitipan Anak dan Satuan PAUD Sejenis (SPS), dan yang sederajat. b. Layanan PAUD untuk usia 2 (dua) sampai dengan 4 (empat) tahun terdiri atas Kelompok Bermain (KB) dan yang sejenisnya. c. Layanan PAUD untuk usia 4 (empat) sampai dengan 6 (enam) tahun terdiri atas Taman Kanak-kanak (TK).

Dengan layanan tersebut dibuat bermaksud untuk dapat mengembangkan tumbuh kembang anak dengan tepat sesuai tahapan umurnya dengan maksimal dan kesiapan anak sebelum memasuki jenjang pendidikan sekolah dasar.

Berdasarkan Peraturan Menteri Pendidikan dan Kebudayaan Republik Indonesia Nomor 137 Tahun 2014 Standar Tingkat Pencapaian Perkembangan Anak pasal 10 poin 1 menjelaskan lingkup perkembangan sesuai tingkat usia anak meliputi aspek nilai agama dan moral, fisikmotorik, kognitif, bahasa, sosial-emosional, dan seni. Hal ini berarti ada enam aspek yang penting dikembangkan oleh layanan pendidikan sejak anak usia dini, salah satunya adalah aspek fisikmotorik.

Fisik-motorik merupakan suatu cara bentuk seseorang dalam mengekpresikan perasaan dan pikiran melalui gerakan. Anak yang sedang mengalami pertumbuhan dan perkembangan menggerakan anggota badannya melalui motorik dengan gerakan yang bermakna. Secara umum perkembangan motorik terbagi dua, yaitu perkembangan motorik kasar dan motorik halus.

Motorik kasar menurut Soetjiningsih \& Ranuh (2013:27) "merupakan aspek perkembangan lokomosi (gerakan) dan postur (posisi tubuh)". Lebih lanjut motorik kasar menurut Mulyani (2018:24) "adalah gerak anggota badan secara kasar atau keras". Hal ini berarti motorik kasar merupakan suatu perkembangan gerak badan secara kasar atau keras. Motorik kasar dan motorik halus saling berkaitan tampak dari adanya gerakan halus saat melakukan gerakan kasar.

Motorik halus menurut Mulyani (2018:30) ialah gerakan yang melibatkan otot-otot halus untuk mengendalikan tangan dan kaki. Lebih lanjut menurut Novita (2016) motorik halus adalah 
kemampuan beraktivitas yang melibatkan otot-otot halus atau kecil yang membutuhkan koordinasi mata dan tangan yang cermat. Hal ini berarti motorik halus merupakan suatu koordinasi gerak mata dan tangan yang melibatkan otot-otot halus atau kecil.

Mengetahui perkembangan motorik ada motorik kasar dan halus. Namun diantara keduanya ada yang lebih penting yaitu motorik halus, karena menurut Setyorini (2016) perkembangan motorik halus cenderung lebih lambat dan bila kemampuan motorik halus anak lemah dapat membuat anak frustasi dalam melakukan tugas sehari-hari seperti makan, memakai sepatu, mengancing baju, dan menjadikan anak kikuk dan sembrono.

Untuk mengetahui motorik halus anak telah tercapai dibuatlah sebuah peraturan kemampuan motorik halus anak yang harus dicapai berdasarkan Peraturan Menteri Pendidikan dan Kebudayaan Republik Indonesia Nomor 137 Tahun 2014 Tentang Tingkat Pencapaian Perkembangan Anak Usia 4-6 tahun meliputi:

Tingkat pencapaian yang diharapkan yaitu melakukan garis vertikal, horizontal, lengkungan kiri/kanan, miring kiri/kanan, dan lingkaran, meniru bentuk, mengontrol gerakan tangan yang menggunakan otot halus (menjumput, mengelus, mencolek, mengepal, memelintir, memilin, memeras), menirukan gerakan manipulatif untuk menghasilkan suatu bentuk dengan menggunakan berbagai benda, menggunakan alat tulis dan alat makan dengan benar, menggunting sesuai dengan pola, menempel gambar dengan tepat.

Banyak strategi pembelajaran yang dapat digunakan untuk anak usia dini. Beberapa strategi dapat meningkatkan kemampuan motorik halus anak. Salah satunya adalah dengan melipat dan menggunting. Melipat dan menggunting adalah salah satu strategi yang memberikan pengalaman menyenangkan. Melalui melipat dan menggunting anak mendapat pengalaman serta kelenturan jemari anak. Melipat dan menggunting disampaikan melalui media disertai contoh dengan suasana komunikasi yang menyenangkan. Komunikasi yang disampaikan harus mengandung pesan, motivasi, dan informasi yang dapat ditangkap oleh anak sehingga dapat melakukan cara melipat dan menggunting dengan baik.

Berdasarkan observasi yang dilakukan peneliti di TK Ikal Widya Kumara Sidakarya, ditemukan berbagai masalah yang dapat diklaim sebagai rendahnya kemampuan motorik halus yaitu menjiplak bentuk belum sempurna, belum terampil dalam memasukan benda pada benang, melipat kertas masih belum terlipat secara simetris, cara menulis anak masih belum begitu benar, kegiatan menempel masih berantakan dan menggunakan gunting belum begitu benar sehingga hasil mengguntingnya tidak sesuai pola.

Dari observasi awal pada hari kamis-jumat tanggal 14-15 bulan Maret tahun 2019 menunjukkan bahwa kemampuan motorik halus anak pada kelompok B1 TK Ikal Widya Kumara Sidakarya masih kurang berkembang secara optimal. Faktor-faktor penyebab kemampuan motorik halus rendah yang sesuai di lapangan, guru menerapkan pembelajaran untuk kemampuan motorik halus masih dengan kegiatan mewarnai, melakukan meronce dengan benang dan sedotan, melakukan kolase, menganyam menggunakan kertas tidak berwarna-warni serta kegiatan menggunting kertas mengikuti pola gambar pada buku bergambar. Kegiatan tersebut dilakukan terus menerus secara bergantian tanpa ada variasi lain sehingga anak cenderung bosan dan karena waktu yang terbatas menyebabkan keterampilan motorik halus belum berkembang secara optimal.

Melihat faktor penyebab masalah di TK tersebut, maka perlu dicari alternatif untuk dapat mengembangkan motorik halus anak sekaligus mengatasi rasa bosan anak. Salah satu alternatif untuk menyelesaikan masalah di TK tersebut adalah menggunakan cara melipat dan menggunting dengan kirigami. Kirigami adalah salah satu kegiatan seni melipat dan seni menggunting yang 
diharapkan dapat membantu guru menstimulasi masing-masing motorik halus anak serta menyenangkan bagi anak.

Bahan dan alat yang dibutuhkan dalam kegiatan kirigami mudah untuk ditemui seperti kertas origami, gunting, pensil, penghapus, penggaris, lem kertas dan buku gambar. Pembuatan kirigami juga mudah untuk dilakukan seperti menurut Sumanto (dalam Deysa, 2015) pertama menentukkan bentuk, bahan dan alat yang diperlukan dahulu; kedua melipat kertas; ketiga digambar dengan pensil bentuk yang diinginkan; keempat hasil gambar dipotong secara bertahap; dan kelima hasilnya ditempel di atas buku gambar menggunakan lem kertas.

Maka dari itu sudah seharusnya guru dapat menggunakan strategi melipat dan menggunting yang praktis dan menyenangkan melalui kirigami dalam mengembangkan aspek motorik halus yang dimiliki oleh anak. Kirigami adalah salah satu strategi yang efektif diterapkan bagi anak didik sebab kirigami dapat mengembangkan pembelajaran dibidang seni, desain grafis dan koordinasi mata-tangan. Hal tersebut sesuai yang dikatakan Temko (dalam Rakimahwati, 2018) Kirigami, the creative art of paper-cutting, is a surprisingly easy craft that requires only paper, a pair of scissors, and sometimes glue. Cutting paper seems to be an instinctive pleasure. At an early age many children like to snip paper into small pieces. Before long they design pictures by pasting to shapes on a background. Papercutting is well recognized to provide educational benefits in the areas of art, math, grapich design, and hand-eye coordination.

Terdapat beberapa penelitian sebelumnya yang dilakukan oleh Novita (2016) yang berjudul "Peningkatan Keterampilan Motorik Halus Melalui Kirigami Pada Siswa Cerebral Palsy Tipe Spastik Di SLB Rela Bhakti I Gamping", serta Gita (2016) yang berjudul "Pengaruh Kegiatan Kirigami Geometri Terhadap Kemampuan Motorik Halus Anak Kelompok B" yang menggunakan kirigami sebagai strategi meningkatkan kemampuan motorik halus.

Telah ditemukan data bahwa kirigami berhasil meningkatkan kemampuan motorik halus anak usia 5-6 tahun dalam melipat empat lipatan dan menggunting sesuai pola geometri sesudah diberikan kegiatan kirigami geometri dan anak juga menjadi antusias dalam mengikuti pembelajaran keterampilan motorik halus melalui kirigami yang dilakukan peneliti tersebut.

Berdasarkan berbagai permasalahan yang telah dipaparkan di atas dan asumsi kirigami dapat meningkatkan kemampuan motorik halus anak, untuk mengkaji lebih luas permasalahannya, maka dilakukan penelitian eksperimen dengan judul Pengaruh Kirigami Terhadap Kemampuan Motorik Halus Anak Kelompok B1 Di TK Ikal Widya Kumara Sidakarya Tahun Ajaran 2018/2019.

\section{METODE}

Penelitian ini dilaksanakan pada anak kelompok B1, pada semester II (genap) di TK Ikal Widya Kumara Sidakarya Tahun Ajaran 2018/2019. Rancangan dalam penelitian ini adalah pendekatan kuantitatif dengan metode penelitian eksperimen. Metode penelitian eksperimen merupakan metode penelitian yang paling produktif, karena jika penelitian tersebut dilakukan dengan baik dapat menjawab hipotesis yang utamanya berkaitan dengan hubungan sebab akibat (Sukardi, 2015:179).

Dalam rancangan ini sampel tidak dipilih secara random dan masih terdapat variabel luar yang ikut berpengaruh terhadap terbentuknya variabel terikat (dependen) maka penelitian ini tergolong Pre-Experimental Design. Jenis desain pra-eksperiment yang digunakan dalam penelitian ini adalah One Group Pretest-Posttest.

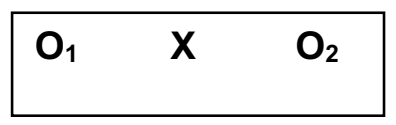




\section{Gambar 1.}

\section{Rancangan Pre-Eksperimental Design}

(Sugiyono, 2015:111)

Keterangan:

$\mathrm{X}$ : Perlakuan (treatment) dengan kirigami.

$\mathrm{O}_{1}$ : Pretest kemampuan motorik halus anak kelompok B1 TK Ikal Widya Kumara Sidakarya sebelum perlakuan.

$\mathrm{O}_{2}$ : Posttest kemampuan motorik halus anak kelompok B1 TK Ikal Widya Kumara Sidakarya setelah perlakuan.

Pada rancangan penelitian One Group Pretest-Posttest ini memiliki tiga tahapan, yaitu (1) pelaksanaan pretest untuk mengukur variabel terikat, (2) pelaksanaan perlakuan atau eksperimen, (3) pelaksanaan posttest untuk mengukur hasil atau pengaruhnya terhadap variabel.

Demikian rancangan penelitian ini, pengaruh perlakuan ditentukkan dengan cara membandingkan skor pretest dan posttest.

Populasi mempunyai arti yang bervariasi. Menurut Sukardi (2015:53) "populasi pada prinsipnya adalah semua anggota kelompok manusia, binatang, peristiwa, atau benda yang tinggal bersama dalam satu tempat dan secara terencana menjadi target kesimpulan dari hasil akhir suatu penelitian". Populasi pada penelitian ini adalah anak kelompok B1 TK Ikal Widya Kumara Sidakarya.

Setiap penelitian dibutuhkan adanya sampel sebab tidak memungkinkan untuk mempelajari semua yang ada pada populasi. Sampel menurut Sukardi (2015:54) "sebagian dari jumlah populasi yang dipilih untuk sumber data peneliti". Teknik sampling yang digunakan dalam penelitian ini adalah Sampling Jenuh. Hal ini disebabkan jumlah populasi yang kurang dari 30 anak. Jadi sampelnya adalah semua populasi anak kelompok B1 TK Ikal Widya Kumara Sidakarya sebanyak 27 anak.

Validitas internal adalah salah satu faktor yang mempengaruhi hasil penelitian. Menurut Setyosari (2015:180) mengatakan "validitas internal bersumber dari pelaksanaan penelitian itu sendiri yang berkaitan dengan perlakuan yang diberikan apakah benar-benar menyebabkan hasil yang diobservasi dalam penelitian".

Jadi, validitas internal adalah validitas yang berkaitan dengan kontrol yang dilakukan terhadap berbagai variabel lain yang dapat mempengaruhi hasil eksperimen. Ancaman validitas internal dalam penelitian ini berupa kematangan atau maturasi, instrumentasi, dan pengujian sebelumnya (pretesting).

Selain faktor eksternal, ada faktor lain yang juga mempengaruhi hasil penelitian adalah faktor yang bersifat eksternal. Variabel eksternal mengacu pada sejauh mana suatu hasil penelitian dapat digeneralisasikan. Menurut Setyosari (2015:192) validitas eksternal merujuk pada generalisasi dan berkenaan dengan seberapa jauh kita dapat menggeneralisasi hasil penelitian diluar latar penelitian. Ancaman validitas eksternal dalam penelitian ini berupa interaksi antara perlakuan dan orang, dan interaksi antara perlakuan dan latar.

Metode pengumpulan data diperlukan untuk mengumpulkan sebuah data dalam penelitian. Menurut Riduwan (2015:24) metode pengumpulan data adalah teknik atau cara-cara yang dapat digunakan oleh peneliti untuk mengumpulkan data dalam keperluan penelitiannya. Data yang 
diperlukan dalam penelitian ini adalah data kemampuan motorik halus anak. Metode pengumpulan data yang digunakan dalam penelitian ini adalah metode observasi dengan checklist.

Variabel penelitian pada dasarnya adalah segala sesuatu objek yang berbentuk apa saja dengan kata lain variabel adalah objek penelitian yang bervariasi yang menjadi titik perhatian dalam suatu penelitian untuk dipelajari. Seperti yang dikatakan Tersiana (2018:67) variabel adalah objek penelitian, atau apa yang menjadi titik perhatian suatu penelitian. Dalam penelitian ini melibatkan dua variabel, yaitu variabel bebas dan variabel terikat.

Variabel bebas atau biasa dikenal juga dengan variabel independent, variabel penyebab atau X. Menurut Siregar (2015:10) variabel bebas (Independent) adalah variabel yang menjadi sebab atau merubah/memengaruhi variabel lain. Variabel bebas dalam penelitian ini adalah kirigami.

Kirigami adalah seni melipat dan menggunting kertas pada lipatan-lipatan kertas untuk mendapatkan hasil yang diinginkan. Adapun alat dan bahan yang digunakan dalam pembuatan kirigami yakni kertas berbentuk bujur sangkar yakni kertas origami yang digunakan penelitian ini, gunting/cutter tajam yang nyaman untuk digunakan, penggaris, pensil, penghapus, lem kertas, dan buku gambar.

Selanjutnya dilakukan teknik atau langkah-langkah pembuatan kirigami meliputi menentukkan bentuk yang ingin dibuat, menyiapkan alat dan bahan, setelah itu dilipat dan digunting sesuai pola yang telah dibuat dan hasilnya ditempel di atas buku gambar. Manfaat yang didapat anak melakukan kegiatan kirigami adalah melatih kemampuan motorik, kognitif, memperkuat emosi antar guru dan anak didik, serta mangajarkan anak untuk fokus, sabar, kerjasama antar anak dan disiplin

Variabel terikat atau biasa dikenal juga dengan variabel dependent, variabel tergantung atau Y. Menurut Siregar (2015:10) variabel terikat (dependent) adalah variabel yang dipengaruhi atau menjadi akibat karena adanya variabel lain (variabel bebas). Variabel terikat dalam penelitian ini adalah kemampuan motorik halus.

Motorik halus adalah suatu gerakan otot yang indah dalam bentuk koordinasi, ketangkasan dan kecekatan dalam menggunakan tangan dan jari jemari yang dipengaruhi matangnya fungsi motorik, fungsi visual yang akurat, dan kemampuan intelek nonverbal. Memiliki karakteristik seperti anak mulai belajar menggunakan anggota badannya dengan meniru gerakan-gerakan yang diajarkan dan sedang aktifnya belajar mengembangkan motorik halus anak.

Manfaat motorik halus pada anak merupakan sebagai alat memperoleh dan meningkatkan berbagai perkembangan, memperoleh penerimaan sosial, tidak mengalami kesulitan melakukan pekerjaan dan dapat menumbuhkan perasaan senang untuk dirinya dalam melakukan kegiatan. Motorik halus berkembang dipengaruhi oleh faktor-faktor yakni dipengaruhi oleh bawaan diri anak yang berasal dari orang tuanya, maupun dari lingkungan yang membimbing dan memberikan kesempatan anak mengembangkan kemampuan motorik halus untuk mencapai kematangan

Instrument diperlukan untuk mengurangi kesalahan yang dapat terjadi ketika melakukan pengumpulan data dalam penelitian. Menurut Tersiana (2018:86) instrument penelitian adalah alat yang digunakan peneliti dalam mengumpulkan data agar pekerjaannya lebih mudah dan hasilnya lebih baik. Instrumen penelitin ini berupa kisi-kisi lembar observasi dan rubrik penilaian.

Sebelum memperoleh data, diperlukan membuat instrumen yang baik dan mampu mengambil informasi dari subjek atau objek yang diteliti. Uji validitas yang dilakukan adalah uji validitas isi. Uji validitas isi berkenaan dengan ketepatan instrumen dalam suatu variabel yang akan diukur, serta ketepatan format instrumen. Menguji validitas isi digunakan pendapat ahli (judgment expert) tentang instrumen yang telah disusun. 
Uji validitas isi yang disusun berupa kerangka isi kisi-kisi lembar observasi dan rubrik penilaian yang diambil dari kurikulum ataupun buku ajar. Isi dikatakan valid apabila pengumpulan data tersebut benar-benar representatif terhadap tujuan pengumpulan data.

Untuk memperoleh analisis data kemampuan motorik halus anak dalam penelitian ini menggunakan statistik uji t. Sebelum dilakukan uji hipotesis terlebih dahulu dilakukan uji prasyarat analisis yaitu uji normalitas sebaran data yang dimaksudkan untuk mengetahui dapat atau tidaknya melakukan uji hipotesis untuk mengetahui sebaran data skor nilai kemampuan motorik halus anak berdistribusi normal atau tidak sehingga dapat menentukan teknik analisis datanya. Kriteria pengujian adalah jika $\chi_{\text {hit }}^{2}<\chi_{\text {tabel' }}^{2}$ maka Ho diterima yang berarti data berdistribusi normal dengan taraf signifikansinya adalah $5 \%$ dan derajat kebebasannya $n-1$.

Hipotesis yang akan diuji adalah untuk membuktikan $\mathrm{H}_{\mathrm{o}}$ ditolak atau diterima, maka Chi Kuadrat hitung $x_{\text {hit }}^{2}$ dibandingkan dengan $x_{\text {tabel }}^{2}$ dengan $\mathrm{dk}=1$. Berdasarkan $\mathrm{dk}=1$ dan kesalahan $5 \%(0,05)$. Jika $x_{\text {hit }}^{2} x_{\text {tabel }}^{2}$ maka $\mathrm{H}_{\mathrm{o}}$ ditolak dan $\mathrm{H}_{\mathrm{a}}$ diterima.

\section{HASIL DAN PEMBAHASAN}

Berdasarkan nilai mean atau nilai rata-rata kemampuan motorik halus sebelum dibelajarkan menggunakan kirigami yaitu $\bar{X}=27,93$, sedangkan nilai mean atau rata-rata kemampuan motorik halus sesudah dibelajarkan kirigami yaitu $\bar{X}=64,22$. Data tersebut menunjukkan bahwa kemampuan motorik halus sesudah dibelajarkan menggunakan kirigami memiliki rata-rata lebih tinggi dibandingkan sebelum dibelajarkan menggunakan kirigami.

Tabel 1.

Rekapitulasi Hasil Deskripsi Kemampuan Motorik Halus Anak Kelompok B1 di TK Ikal Widya Kumara Sidakarya Tahun Ajaran 2018/2019

\begin{tabular}{cccc}
\hline Hasil Analisis & Pretest & Hasil analisis & Posttest \\
\hline Mean & 27.93 & Mean & 64.22 \\
\hline Minimum & 25 & Minimum & 56 \\
\hline Maksimum & 38 & Maksimum & 81 \\
\hline Rentangan & 14 & Rentangan & 26 \\
\hline Banyak Kelas & 6 & Banyak Kelas & 6 \\
\hline Panjang Kelas & 3 & Panjang Kelas & 4 \\
\hline
\end{tabular}

Sebelum diberikan perlakuan (treatment) berupa kirigami distribusi frekuensi kemampuan motorik halus didapat rentangan 25-27 adalah 15 dengan nilai tengah 26 . Rentangan 28-30 adalah 0 dengan nilai tengah 29. Rentangan 31-33 adalah 11 dengan nilai tengah 32 . Rentangan 34-36 adalah 0 dengan nilai tengah 35 . Rentangan 37-39 adalah 1 dengan nilai tengah 38 dan rentangan 40-42 adalah 0 dengan nilai tengah 41 .

Setelah diberikan perlakuan (treatment), diakhir eksperimen diperoleh hasil posttest yaitu memiliki rentangan 56-59 adalah 9 dengan nilai tengah 57,5. Rentangan 60-63 adalah 8 dengan nilai tengah 61,5. Rentangan 64-67 adalah 0 dengan nilai tengah 65,5 . Rentangan $68-71$ adalah 5 
dengan nilai tengah 67,5 . Rentangan $72-75$ adalah 4 dengan nilai tengah 73,5 dan rentangan 76 79 adalah 1 dengan nilai tengah 77,5 .

Hasil uji normalitas data pretest, diperoleh Chi-Kuadrat hitung $\left(\chi_{\text {hit }}^{2}=8,70\right)$ kemudian nilai tersebut dibandingkan dengan Chi-Kuadrat tabel $\left(\chi_{\text {tabel }}^{2}=11,07\right)$. Hal ini menunjukkan bahwa $\chi_{\text {hit }}^{2}$ $<\chi_{\text {tabel }}^{2}$ berarti data hasil kemampuan motorik halus pretest berdistribusi normal.

Kemudian hasil uji normalitas data posttest, diperoleh Chi-Kuadrat hitung $\left(\chi_{\text {hit }}^{2}=10,71\right)$ kemudian nilai tersebut dibandingkan dengan Chi-Kuadrat tabel $\left(x_{\text {tabel }}^{2}=11,07\right)$. Hal ini menunjukkan bahwa $\chi_{\text {hit }}^{2}<\chi_{\text {tabel }}^{2}$ berarti data hasil kemampuan motorik halus posttest berdistribusi normal.

Berdasarkan hal itu maka uji statistik yang digunakan dalam penelitian ini adalah uji beda mean (uji t) dengan menggunakan uji varians. Setelah perhitungan selesai maka dilakukan uji signifikasi yaitu dengan cara membandingkan antara $t_{\text {hitung }}$ dengan $t_{\text {tabel }}$ yang diperoleh. Dengan kriteria jika $t_{\text {hitung }}>t_{\text {tabel, maka }} \mathrm{H}_{0}$ ditolak, berarti terdapat pengaruh yang signifikan kirigami terhadap kemampuan motorik halus anak kelompok B1 TK Ikal Widya Kumara Sidakarya

Diperoleh $t_{\text {hitung }}=33,55$ sedangkan taraf signifikansi $5 \%$ dengan $\mathrm{dk}=26$ diperoleh $\mathrm{t}_{\text {tabel }}=$ 2,056 , sehingga $t_{\text {hitung }}>t_{\text {tabel. }}$. Dengan hasil yang tersebut disimpulkan bahwa $\mathrm{H}_{0}$ ditolak, berarti terdapat pengaruh yang signifikan kirigami terhadap kemampuan motorik halus anak kelompok B1 TK Ikal Widya Kumara Sidakarya.

Tabel 2. Rekapitulasi Analisis Uji-t

\begin{tabular}{cccccc}
\hline No & Populasi & $\mathrm{N}$ & $\mathrm{t}_{\text {hitung }}$ & $\mathrm{t}_{\text {tabel }}$ & Status \\
\hline 1 & $\begin{array}{c}\text { Kelompok } \\
\text { B1 }\end{array}$ & 27 & 33,55 & 2,056 & $\begin{array}{c}\mathrm{H}_{0} \\
\text { ditolak }\end{array}$
\end{tabular}

Hasil temuan ini menunjukkan bahwa kirigami berpengaruh terhadap kemampuan motorik halus anak. Hal ini disebabkan kirigami yang dibuat pada TK tersebut menggunakan kertas dan gunting atau cutter dengan langkah-langkah melipat kertas sebanyak tiga lipatan terlebih dahulu, kemudian gunting hasil gambar yang sudah dibuat sebelumnya pada lipatan kertas untuk mendapat hasil potongan yang rapi.

Hal tersebut sesuai dengan Mitarwan (2011:6) yang menjelaskan kirigami adalah seni melipat dan menggunting kertas pada lipatan-lipatan kertas untuk mendapatkan hasil yang diinginkan. Maka dari itu kirigami dapat meningkatkan kemampuan motorik halus anak, tampak dari ujung-ujung jari anak menekan kertas yang merupakan latihan efektif melatih keterampilan motorik halus.

Sebab motorik halus dapat meningkat tampak dari adanya koordinasi pergerakan yang berkelanjutan secara konsisten dan automatis, yang diterapkan di dalam sistem syarat lalu disimpan di memory. Hal tersebut didukung oleh Balitang Diknas (dalam Yusuf dan Sugandhi, 2013:53) menjelaskan karakteristik motorik halus pada usia 4-6 tahun anak dapat belajar mengurus diri sendiri, menjahit sederhana, menggunting dan melipat kertas sederhana.

Selain hal tersebut di atas kirigami juga dapat mengembangkan kognitif anak tampak dari konsentrasi anak dilatih saat mengikuti instruksi langkah demi langkah, sehingga mengembangkan kognitif, kemandirian serta bakat anak dalam seni.

Kegiatan kirigami ini dilakukan sebanyak 10 kali dengan kegiatan yang berbeda disetiap pembelajaran agar bervariasi. Sebab pada motorik halus dibutuhkan kegiatan yang bervariasi agar 
anak tidak bosan melaksanakan proses pembelajaran mengembangkan motorik halus seperti kirigami.

Berdasarkan penelitian Gita (2016), bahwa kirigami dapat meningkatkan kemampuan motorik halus anak dengan teknik analisis data harga $U$ hitung lebih kecil dari pada $U$ tabel $(127<401)$. Hal ini berarti kegiatan kirigami geometri berpengaruh terhadap kemampuan motorik halus kelompok B usia 5-6 tahun. di TK Muslimat NU 08 Darul Rohmah Laren Lamongan.

Demikian dapat disimpulkan bahwa terdapat pengaruh yang signifikan kirigami terhadap kemampuan motorik halus anak kelompok B1 TK Ikal Widya Kumara Sidakarya Tahun Ajaran 2018/2019.

\section{PENUTUP}

Berdasarkan hasil penelitian yang diperoleh dapat disimpulkan bahwa terdapat pengaruh kirigami terhadap kemampuan motorik halus anak. Hasil analisis data nilai rata-rata atau mean kemampuan motorik halus sebelum menerapkan kirigami $\bar{X}=27.93$, data minimal $=25$, data maksimal $=38$, dengan rentangan $=14$, banyak kelas $=6$ dan panjang kelas $=3$.

Sedangkan nilai rata-rata atau mean kemampuan motorik halus sesudah menerapkan kirigami yaitu $\bar{X}=64.22$, data minimal $=56$, data maksimal $=81$, dengan rentangan $=26$, banyak kelas $=6$ dan panjang kelas $=4$. Data tersebut menunjukkan bahwa kemampuan motorik halus sesudah menerapkan kirigami memiliki rata-rata lebih tinggi dibandingkan dengan sebelum menerapkan kirigami.

Setelah perhitungan selesai, dilanjutkan dengan uji signifikasi yaitu dengan cara membandingkan antara $t_{\text {hitung }}$ dan $t_{\text {tabel }}$ yang diperoleh. Dengan kriteria jika harga $t_{\text {hitung }}>$ dari $t_{\text {tabel }}$, maka $\mathrm{H}_{0}$ ditolak. Pada taraf $5 \%$ dengan $\mathrm{dk}=\mathrm{n}-1$. Data yang diperoleh menunjukkan bahwa $\mathrm{t}_{\text {hitung }}>$ dari $t_{\text {tabel, }}$ dimana harga $t_{\text {hitung }}=33,55$ dan $\mathrm{t}_{\text {tabel }} 2,056$, maka $\mathrm{H}_{0}$ ditolak dan $\mathrm{H}_{\mathrm{a}}$ diterima. Pada taraf signifikansi $5 \%$ dengan $\mathrm{dk}=\mathrm{n}-1$.

Jadi data tersebut menunjukkan bahwa kirigami berpengaruh terhadap kemampuan motorik halus anak kelompok B1 di TK Ikal Widya Kumara Sidakarya Tahun Ajaran 2018/2019.

Berdasarkan hasil penelitian ini, maka saran yang dapat diberikan adalah Kepada kepala sekolah agar hasil penelitian ini dijadikan tambahan ide baru dalam mengembangkan kemampuan motorik halus dalam pembelajaran sebab kirigami berpengaruh terhadap kemampuan motorik halus anak.

Pemberian kegiatan untuk mengembangkan motorik halus harus bervariasi agar anak tidak cepat bosan dan mengakibatkan lemahnya motorik halus. Maka dari itu guru hendaknya menggunakan kegiatan yang mendukung berbagai kemampuan anak, misalnya kegiatan kirigami dalam meningkatkan kemampuan motorik halus agar anak menjadi tertarik melakukan sebab menyenangkan bagi anak dengan adanya banyak variasi yang dihasilkan.

Kepada peneliti lain agar hasil penelitian ini dapat menjadi informasi dan tambahan ilmu yang berharga bagi peneliti dalam bidang pendidikan dan sebagai referensi untuk penelitian selanjutnya.

\section{UCAPAN TERIMAKASIH}

Terselesaikannya skripsi ini, banyak memperoleh bantuan dari berbagai pihak. Oleh karena itu pada kesempatan ini disampaikan ucapan terimakasih kepada yang terhormat. 
1. Prof. Dr. I Nyoman Jampel, M.Pd., Rektor Universitas Pendidikan Ganesha atas kebijakan serta program-program yang dilaksanakan di Undiksha.

2. Prof. Dr. Ni Ketut Suarni, M.S, Kons, Dekan Fakultas Ilmu Pendidikan Ganesha atas kebijakan serta arahannya selama penyusunan skripsi ini.

3. Drs. I Made Suarjana, M.Pd, Ketua Jurusan Pendidikan Dasar yang telah memberikan legalitas dan memberikan pengarahan selama penyusunan skripsi ini.

4. Dr. Putu Aditya Antara, S.Pd., M.Pd, Koordinator Program Studi PGPAUD Fakultas Ilmu Pendidikan Ganesha yang telah memberikan motivasi dan bimbingan selama penyusunan skripsi ini.

5. Drs. I Wayan Wiarta, S.Pd, M.For, Ketua UPP PGSD dan PGPAUD Undiksha Denpasar yang telah memberikan kesempatan menyusun skripsi ini.

6. Luh Ayu Tirtayani, S.Psi., M.Psi., Psikolog, Sekretaris PGPAUD Denpasar yang telah memberikan arahan dan bimbingan selama penyusunan skripsi ini.

7. Drs. Ida Bagus Surya Manuaba, S.Pd., M.For selaku Pembimbing I, yang telah memberikan arahan, motivasi serta membimbing dengan ketelitian, kecermatan, dan kesabaran selama penyusunan skripsi ini.

8. Gusti Ngurah Sastra Agustika, S,Si., M.Pd selaku Pembimbing II yang telah memberikan arahan, motivasi serta membimbing dengan ketelitian, kecermatan, dan kesabaran selama penyusunan skripsi ini.

9. Ni Wayan Sumarwati, Kepala TK Ikal Widya Kumara Sidakarya yang memberikan ijin untuk melaksanakan penelitian eksperimen ini di TK tersebut.

10. Ni Putu Kamiasih, Guru kelompok B1 di TK Ikal Widya Kumara Sidakarya yang telah membantu dalam melaksanakan penelitian eksperimen ini.

11. Bapak dan ibu Dosen serta staf pegawai di lingkungan jurusan PGPAUD, Undiksha kampus UPP II Denpasar yang banyak memberikan masukan, saran dan nasihat selama penyusunan skripsi ini.

12. Rekan-rekan mahasiswa yang telah memberikan informasi, saran dan dukungan selama penyusunan skripsi ini.

13. Keluarga yang selalu memberikan doa, dukungan moral maupun material selama proses pendidikan yang ditempuh.

Terselesainya skripsi ini masih jauh dari sempurna mengingat keterbatasan yang dimiliki, untuk itu sangat diharapkan kritik dan saran yang bersifat membangun demi kesempurnaan skripsi ini. Akhir kata, diharapkan penelitian ini bermanfaat dalam kemajuan pendidikan anak usia dini. 


\section{DAFTAR PUSTAKA}

Deysa, Rarasati. 2015. "Peningkatan Kemampuan Motorik Halus Anak Autis Melalui Media Kreasi Kirigami Di SLB Autis Dian Amanah Yogyakarta.” Universitas Negeri Yogyakarta.

Gita, Tita Norma. 2016. "PENGARUH KEGIATAN KIRIGAMI GEOMETRI TERHADAP KEMAMPUAN MOTORIK HALUS ANAK KELOMPOK B.” Jurnal PAUD Teratai 5 (2): $142-48$.

Mitarwan, M. Hamid. 2011. Membuat Gift Cards Kirigami Bunga, Buah, Dan Sayuran. Jakarta: PT. Gramedia Pustaka Utama.

Mulyani, Novi. 2018. Perkembangan Dasar Anak Usia Dini. Yogyakarta: Gava Media.

Novita, Grace Chintia. 2016. "Peningkatan Keterampilan Motorik Halus Melalui Kirigami Pada Siswa Cerebral Palsy Tipe Spastik Di SLB Rela Bhakti Gamping.” IOSR Journal of Economics and Finance. Universitas Negeri Yogyakarta.

Kementerian Pendidikan. 2014. Peraturan Menteri Pendidikan Dan Kebudayaan Republik Indonesia Nomor 137 Tahun 2014 Tentang Standar Nasional Pendidikan Anak Usia Dini.

Kementerian Pendidikan. 2014. Peraturan Menteri Pendidikan Dan Kebudayaan Republik Indonesia Nomor 146 Tahun 2014 Tentang Kurikulum 2013 Pendidikan Anak Usia Dini.

Rakimahwati, Nora Agus Lestari, and Sri Hartati. 2018. "Pengaruh Kirigami Terhadap Kemampuan Motorik Halus Anak Di Taman Kanak-Kanak." Jurnal Obsesi : Jurnal Pendidikan Anak Usia Dini 2 (1): 102-10. https://obsesi.or.id/index.php/obsesi/article/ download/13/12.

Riduwan. 2015. Skala Pengukuran Variabel-Variabel Penelitian. Bandung: Alfabeta.

Setyorini, Endang. 2016. "Upaya Meningkatkan Keterampilan Motorik Halus Melalui Kirigami Pada Anak Kelompok B2 TK ABA Thoyibah Banyuanyar Tahun Ajaran 2015/2016.” Kumara Cendekia 4 (4): 1-10.

Setyosari, Punaji. 2015. Metode Penelitian Kuantitatif Dan Pengembangan. Jakarta: Prenadamedia Group.

Siregar, Syofian. 2015. Metode Penelitian Kuantitatif: Dilengkapi Perbandingan Perhitungan Manual \& SPSS. Jakarta: Kencana.

Soetjiningsih, dan Gde Ranuh. 2016. Tumbuh Kembang Anak Edisi 2. 2nd ed. Jakarta: EGC.

Sugiyono. 2015. Metode Penelitian Pendidikan Pendekatan Kuantitatif, Kualitatif, Dan R\&D. Bandung: Alfabeta.

Sukardi. 2015. Metodologi Penelitian Pendidikan Kompetensi Dan Praktiknya. Jakarta: PT. Bumi Aksara.

Tersiana, Andra. 2018. Metode Penelitian. Yogyakarta: Star Up. 
Maha Dewi, dkk., Vol. 7(1), 2019, 88-99

Triwiyanto, Teguh. 2014. Pengantar Pendidikan. Jakarta: Bumi Aksara.

Yusuf, S, dan N Sugandhi. 2013. Perkembangan Peserta Didik. Jakarta: Rajawali Pers. 